\title{
NEWS OF THE ASSOCIATION
}

\section{Minutes OF the ThiRTy-ThiRd ANNUAl Business MeEting}

\author{
Chicago, Mlinois, 5 November 1989
}

The 33rd annual Business Meeting was called to order by President Richard Antoun. A motion was made and carried to accept the minutes of the 1982 meeting as published in the MESA Bulletin 17.1 (July 1983) pp. 113-120.

Executive Secretary's Report was presented by Michael E. Bonine.

1989 Membership. The November 1, 1983 membership stood at 1193-a slight decrease from the 1982 membership of 1217. Total membership was comprised of 836 Full, 152 Associate, 210 Student, and 3 Institutional Members. New members added to the Roster were 193 , but there is an annual loss of about $10 \%$ of the renewing members. Two more Institutional Members have joined MESA this year; they are the University of Arizona and the University of Utah. MESA is very pleased to welcome them as Institutional Members and also wishes to thank the University of Texas for continuing its support this year.

Institutional Members receive all MESA publications. In addition, Institutional Members now receive two free registrations and two free banquet tickets for the MESA Annual Meeting; they also receive two free sets of mailing labels (\$100 each).

The MESA Secretariat's office in Tucson began in 1983 to handle membership dues, instead of the Cambridge University Press as had been done before. This centralization of the membership data has proven very satisfactory and allows better control over finances, makes it easier to compile statistics, and enhances contact with the membership.

Renewal Notices. In the fall of 1983 the Secretariat's office sent out the 1983 Renewal Notices to members who did not fully complete the questionnaire sections of the forms. This information is needed to compile a new Roster of Members.

For the convenience of our members, the 1984 Renewal Forms will be condensed. Dues will remain the same, with no increase next year ( $\$ 45$ for Full and Associate Members; $\$ 20$ for Student and Retired Members).

Roster of Members. The Roster of Members is in the process of being compiled, using the new computer system purchased by the MESA office this summer. The new Roster will include a "specialties" section and more information on each member than the 1982 Roster. Bonine apologized for the delay in getting the Roster in print, but compiling the additional information is time consuming, even with the new computer.

Contributions. Bonine thanked contributors who supported MESA in 1983. A total of $\$ 5,500$ was contributed by 70 individuals, which included 17 Supporting Members and four new Life Members. The new Life Members are: Nikki Keddie, Ann M. Lesch, Seif Wady Romahi, and Ali Zamouri.

MESA is grateful for the financial support of the Exoxon Oil Company for its gift of $\$ 5,000$ and the Gulf Oil Company, which donated $\$ 1,000$ to MESA this year.

National Endowment for the Humanities Challenge Grant. An application was submitted 31 May 1983 to the National Endowment for the Humanities for a 
Challenge Grant of $\$ 150,000$, with matching funds to be raised by MESA on a three-to-one basis. Of the total $\$ 600,000$, an endowment of $\$ 500,000$ would be established to provide permanent, long-term support for the services and activities of MESA. The remaining $\$ 100,000$ would be used for various startup activities and for the fund raising itself. The official announcement of the recipients of the grants will be made in December 1983.

Library of Congress Near East Union List Project. The Library of Congress Near East Union List Project, sponsored by the National Endowment for the Humanities, will terminate this year. MESA has received the last payment of the funding. The project was designated to end 31 March 1985 , but because the funds have been exhausted the project will end this year.

The Ford Foundation. The Ford Foundation made its final payment towards the Visiting Scholars Fund for 1983. The Foundation may be willing to continue its support for visiting scholars under slightly different conditions. This possibility will be pursued.

Financial Statement. See Attachment 1.

Annual Elections. Howard Reed, Chairman of the 1983 Nominating Committee, first announced the other members of the 1983 Nominating Committee. They are: Lisa Anderson (Harvard University), Barbara Stowasser (Georgetown University), Herbert Bodman (University of North Carolina), and Michael Fischer (Rice University).

Reed also thanked the candidates of the 1984 election. They are: President Elect: Kemal H. Karpat (University of Michigan), Richard H. Nolte (International Advisory Associates); Board of Directors: Peter F. Abboud (University of Texas at Austin), Dale F. Eickelman (New York University), John L. Esposito (College of the Holy Cross), and Donald Quataert (University of Houston).

The winners of the election were Karpat, Eickelman, and Esposito.

Names submitted by the Board of Directors for possible candidates for the 1984 Nominating Committee are: William Beeman (Brown University), John Voll (University of New Hampshire), Leonard Helfgott (Western Washington University), Leila Fawaz (Tufts University), Roderic Davison (George Washington University), Nazif Shahrani (Pitzer College), William C. Hickman (UC, Berkeley), Irene A. Bierman (UCLA), Manfred Wenner (Northern Illinois University), and Jerome Clinton (Princeton University). (An additional name was submitted from the floor; that person was not a member and, hence, not eligible.)

A motion was made and seconded to accept the above members as possible candidates for the 1984 Nominating Committee. [The motion passed.]

Of the above names, five will be elected in the Spring to serve on the Nominating Committee to select the candidates for the 1984 election.

Dissertation Awards. There were five entries this year. Members are encouraged to publicize the availability of the awards and notify MESA of possible entrants.

The winner of the 1983 Humanities Dissertation Award is Margaret L. Caton, UCLA, for her entry, entitled "The Classical Tasnif: A Genre of Persian Vocal Music."

The winner of the 1983 Social Sciences Dissertation Award is Beatrice F. Manz, Howard University, for her entry, entitled "Politics and Control under Tamerlane."

The awards will be presented at the banquet.

International Journal of Middle East Studies. IJMES Editor, Afaf Lutfi al-Sayyid Marsot, notified the Board of her wish to retire as Editor at the end of 1984. A 
new editor should be appointed by June 1984 to provide for a smooth transition period. A notice will be printed in the next MESA Newsletter. Anyone interested in applying for the position may contact the Secretariat's office.

Financial Development Committee. President Antoun stressed the importance of increased effort towards soliciting funds for the financial development of MESA. A Financial Development Committee has been appointed to initiate a campaign for soliciting funds for the Association. The Committee is composed of: Richard Antoun (SUNY, Binghamton), William O. Beeman (Brown University), James Bill (University of Texas at Austin), Michael E. Bonine (University of Arizona), Gene Garthwaite (Dartmouth College), Richard H. Nolte (International Advisory Associates), Howard Reed (University of Connecticut), R. Bayly Winder (New York University), and I. William Zartman (Johns Hopkins University-SAIS).

President Antoun called on the support of all members to contribute themselves and to approach the administration of their institution for Institutional Memberships. This is especially important within the next three years if MESA is granted the NEH Challenge Grant. Members are asked to provide the Financial Committee with names of possible sources of funding. President Antoun emphasized the hope that all members get involved and pull together toward a firmer financial foundation for the Middle East Studies Association.

Michael Bonine and his staff were recommended for writing the proposal they submitted to NEH for the Challenge Grant.

Ethics and Resolutions. A draft resolution concerning government research grants was submitted by the Board to the membership for discussion. The resolution voiced concern over the Requests for Proposals (RFPs) from the Defense Academic Research Support Program (DARSP), a special division of the Defense Intelligence Agency (DIA).

A great amount of discussion, both pro and con, followed. Finally, a motion was made and seconded to table the discussion. [The motion passed.] The Ethics Committee, chaired by Marilyn Waldman, will investigate the matter further. Members were asked to contact Waldman with their comments.

Censorship. Marsha McClintock, President of Middle East Librarians' Association, complained of several instances of censorship. Attempts at censorship have been toward the following: the film by Elizabeth Fernea entitled Women under Siege, a publication entitled "Magazines for Librarians," and the University of Arizona Near Eastern Center Outreach Program.

The Librarians' Association has unanimously passed the following resolution objecting to this censorship. (It will be printed in the upcoming issue of $M E L A$ Notes):

We move that the Middle East Librarians' Association speak out in support of free distribution of and access to material and that the Middle East Librarians' Association deplore any restriction of materials by any interest groups.

McClintock requested the Ethics Committee to phrase a similar issue to the membership on freedom of expression.

New Business. Ira Lapidus proposed a resolution to thank the University of Chicago staff for organizing and contributing a successful 1983 Annual Meeting. [Motion passed unanimously.]

A motion was made and seconded to adjourn the meeting. [The motion passed.] 


\section{ATTACHMENT 1}

CASH DISBURSEMENTS

(For Nine Months Ending September 30, 1983)

Cambridge University IJMES Costs

$\$ 28,811.00$

1983 Annual Meeting Expenses

$1,839.73$

MESA BULLETIN:

Typing and Editorial Costs

Other

$1,631.63$

46.00

MESA Newsletter:

Printing

$2,365.75$

Postage

157.44

Elections:

$\begin{array}{ll}\text { Ballot Printing } & 491.80\end{array}$

Mailing $\quad \mathbf{4 1 1 . 1 0}$

Accounting Audit $\quad \mathbf{2 , 3 2 5 . 0 0}$

Office Staff

$4,806.91$

Office Supplies

610.98

Telephone

$1,074.21$

Postage

$1,942.78$

Printing

578.50

169.56

Xeroxing

80.72

Interest Expense

124.50

MESA Brochure

200.00

Grant to Library of Congress

Near East Union List Project

$51,000.00$

Computer Equipment

$10,181.75$

441.60

Typew riter

53.76

Future Annual Meetings

$1,129.00$
633.60

Computer Maintenance Contract

Office Furniture

50.46

Bank Exchange Fees

106.46

Miscellaneous

TOTAL CASH DISBURSEMENTS

$\$ 111,264.24$ 
STATEMENT OF CASH RECEIPTS

(For Nine Months Ending September 30, 1983)

Membership Dues:

Individual

New Life Members

$\$ \quad 44,351.50$

Institutional

$4,000.00$

$1,000.00$

Annual Meeting Income

$9,739.82$

Advertising Income

$1,612.01$

Mailing List Rental

$1,660.00$

Publication Sales:

30.00

Abstracts

$1,211.00$

Directory

20.00

Binder Book

189.50

Bulletins

44.00

Images

121.93

Royalties of Binder Book

$2,009.37$

Interest Income

$1,510.00$

Individual

$5,000.00$

Exxon

$1,000.00$

Grants:

Gulf Oil

National Endowment for the Humanities

$51,000.00$

Kunstadter Family Foundation

$1,000.00$

500.00

Miscellaneous Income

TOTAL CASH RECEIPTS

$\$ 125,504.13$

CASH BALANCE ANALYSIS

(@ September 30, 1983)

\section{Beginning Balance December 31, 1982}

Checking Account

Savings Account

$\$ \quad 1,947.68$

$2,272.06$

IDS Savings Account

$18,289.59$

University of Arizonal Expense Account Deposit

TOTAL BEGINNING CASH BALANCE $\$ 23,544.21$

ADD: Cash Receipts

$\$ 125,504.13$

LESS: Cash Disbursements

$(\$ 111,264.24)$

Ending Balance Q September 30, 1983

Checking Account

Savings Account

$\$ \quad 3,148.61$

$2,363.04$

IDS Savings Account

$32,207.98$

University of Arizona Expense Account Deposit

64.47

TOTAL ENDING CASH BALANCE

$\$ 37,784.10$ 